\title{
織機発生騒音のレベルと出力
}

（織物工場の騒音調査・その 3 )

\begin{abstract}
正会員前田敏男*
準会員 水畑雅行*****
\end{abstract}

\author{
同
}

同

\section{1. 騒音防止対策のための室内騷音レベル基準値}

織物工場の室内騒音レベルは第 1.2 図（その1）の実 線をるつて $\pm 2 \mathrm{~dB}$ の範围で推定でき、点線の值を用い れば騒音防止上充分安全である。

一般仙室内全表面積 $S$ 、平均吸音率 $\bar{\alpha}$ の工場内で

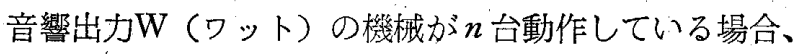
室内平均エネルギー密度 $E$ は $E=4 n \mathrm{~W} / c S \bar{\alpha}$ であるか ら室内平均レベル $\bar{L}$ は

$$
\bar{L}=L_{W}-10 \log \frac{S}{n}+10 \log \frac{4}{\bar{\alpha}} \mathrm{dB}
$$

但し $L_{W}=10 \log \left(W / 10^{-12}\right)$ : 機械1台のパワーレベル で表される。本調査の場合もての関係が近似的に成立す るとみなし、第1.1表において $10 \log (S / n)=6.8+9 \log$ ( $F / n)$ の関係があるから、これを（1）に入れると

$$
\bar{L}=L_{W}-9 \log \frac{F}{n}+10 \log \frac{4}{\bar{\alpha}}-6.8 \mathrm{~dB}
$$

となり、第 1.2 図の傾斜に一致する。

ここで $F / n=10 \mathrm{~m}^{2}$ 亿対する実線の值、 $90 \mathrm{~dB}$ をもつ て騒音防止対策のための室内騒音レベル 基準值とした い。調查せる工場室内の平均吸音率 $\bar{\alpha}$ は 0.2 と考元られ るから、更 $\geq 0.3$ に増せば $\bar{L}$ は約 $2 \mathrm{~dB}$ 低下し、充分安 全になる。従つて $F / n \geq 10 \mathrm{~m}^{2}, \bar{\alpha} \geq 0.3$ と規制すること ができれぱ、工場室内平均レベルは $90 \mathrm{~dB}$ 以下になるこ とが期待できるであろう。

\section{2. 発生騷音レベルと測定ピーク值}

織機発生騒音の主力であるピッカー衝擊音は 90 120 回/分のピッチで発生し、高速度レベルレコーダによる 記録では Writing Speed (記録速度)を早くすればする 程ピーク值が高くなりレベルを決定するてとができな い。第 3.1 図では記録速度 $400 \mathrm{~dB} / \mathrm{sec}$ 以上で録音テー プの飽和がみられる。とのような衝撃音を測定する方法 の規格も現在では定つておらず、測定器も入手できな い。ここでは現場测定の便宜上すべて JIS 規格の騒音計 を用いて得られるピーク值をとるととにした。第 2.3 図 の記録と同時に騒音計の読みをとつて比較し、あらゆる 点で最もよく一致する記録速度として $63 \mathrm{~dB} / \mathrm{sec}$ 決定 した。第 2.6 図はての方法によるピーク值である。ての 場合記録速度を63より早くすると距離減毫の傾斜が急に なり、遅くすると傾斜が緩がになるとが喼められた。

\section{3. 騒音出力に関する考察}

本調查の際、織機 1 台だけ動作した場合の測定值が第

* 京大教授
$* * *$ 京大助教授
$*$ 神戸大助教授 $* * * *$ 京大大学院

○前川純一*** 同 桜井美 政****
松 浦邦 男**

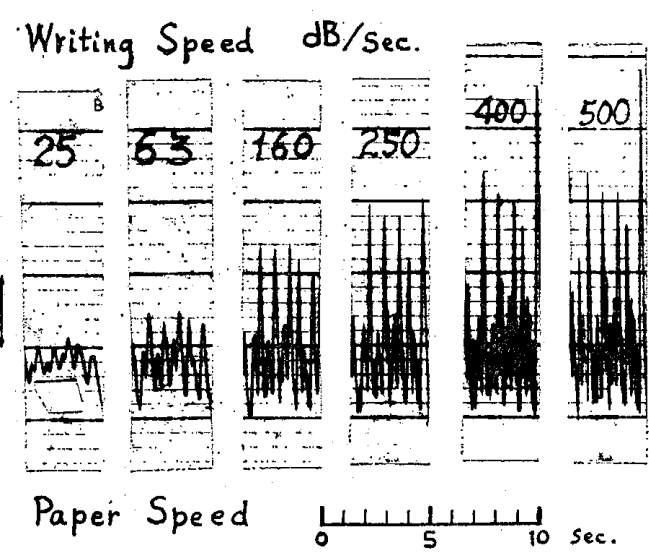

第3.1 図 広巾機（第 2.1 図）ピッカーより距離 $50 \mathrm{~cm}$ の点における録音再生波形

\begin{tabular}{|c|c|c|c|c|c|}
\hline \multirow{2}{*}{ 工場 } & \multicolumn{3}{|c|}{ 機 心より の距 離* } & \multirow{2}{*}{ 織機の型式 } & \multirow{2}{*}{ 駆 動 法 } \\
\hline & 0 & $1 \mathrm{~m}$ & $2 \mathrm{~m}$ & & \\
\hline $\begin{array}{l}\text { B } \\
\text { C } \\
\text { D } \\
\text { E } \\
\text { " } \\
\text { F } \\
\text { "' } \\
\text { " } \\
\text { " }\end{array}$ & $\begin{array}{l}91 \\
93 \\
91 \\
87 \\
91 \\
89 \\
91 \\
87 \\
93 \\
93 \\
89\end{array}$ & $\begin{array}{l}88 \\
90 \\
89 \\
85.5 \\
88 \\
87 \\
89 \\
86 \\
91 \\
91 \\
87\end{array}$ & $\begin{array}{l}\overline{-} \\
\overline{84} \\
\frac{84}{86} \\
88 \\
84 \\
89 \\
89 \\
86\end{array}$ & 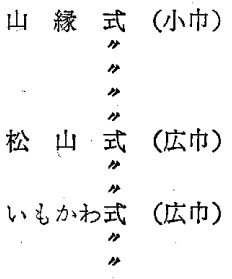 & 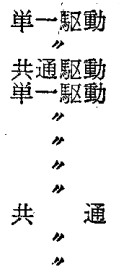 \\
\hline 平均 & 90.4 & 88.3 & 86.6 & & \\
\hline
\end{tabular}

第3.1 表 織機単独発生騒音レベル実測值 $(\mathrm{dB})$

3.1 表である。乙の值は室内で点音源からの距離 $d$ の点 の騒音レベルを表す式

$$
L=L_{W}+10 \log \left\{\frac{1}{4 \pi d^{2}}+\frac{4(1-\bar{\alpha})}{S \bar{\alpha}}\right\} \mathrm{dB}
$$

に(2)式から求めた $L_{W}$ の值を入れて計算した值より、 音源寸法が大きいだけ低くなる筈である。とてろが 0.2 とおいて計算すると Y工場では $L_{W}=89.8 \mathrm{~dB} d=$ $1 \mathrm{~m}$ のとき $83 \mathrm{~dB} d=2 \mathrm{~m}$ で $81.6 \mathrm{~dB}_{\text {。 }}$ N工場では $L_{W}$ $=94.7 \mathrm{~dB} d=1 \mathrm{~m}$ で $86.6 \mathrm{~dB}, d=2 \mathrm{~m}$ で $84.1 \mathrm{~dB}$ (そ の他略）となりいずれも第 3.1 表の実測值の方が数 $\mathrm{dB}$ 大きい。乙れ測定に騒音計の示すピーク值をとつてい るため、パワーを用いて計算したものと一致しないるの と考学引れる。ゆ穴定常的な連続騒音出力がある場合 には便利に用いられるパワーレベルが、との場合のよう な衙撃音に対して厳密には適用できないといえるだろ う。従つて先に (2) 式上り平均吸音率后を增すことに より、室内平均レベルが低下するてとを期待したが、そ の効果にやや不安が残る。てのような衝撃音に関する問 題㥫今後の研究課題とすべきであうう。 